UDK: 37.015.3:159.954]:[37.091.33-027.22:796

Stručni rad

Primljeno: 9. 7. 2021.

Prihvaćeno za štampu: 25. 11. 2021.

Amina Đipa, MA

Pedagoški fakultet Univerziteta u Sarajevu

amina.dipa1@gmail.com

\title{
POVEZANOST IGRE I KREATIVNOSTI: PODSTICANJE KREATIVNOSTI KROZ IGRU
}

\section{Sažetak:}

Zemlje sirom svijeta kontinuirano rąmatraju kako pripremiti djecu da postanu produktivne odrasle osobe, uzpreispitivanje vjestina i sposobnosti potrebnib na radnom mjestu. Jedna od ključnih vještina koja se posebno ističe jeste kreativnost. Rano djetinjstvo predstavlja zlatan period u kojem je iznimno važno poticati kreativnost, a jedan od načina je upravo putem igre. Poznato je da je igra najznačniji djetetov vid učenja u predškolskom periodu, stoga istu treba iskoristiti za stvaranje kreativnih procesa koji su najvise vidljivi tokom raqlicitith vrsta igara. U vremenu brith $i$ značajnih promjena, bitno je djeci ostaviti prostora za igru, jer povoljno potič ne samo na tjelesni, intelektualni, emocionalni i socijalni raqvoj djece već $i$ na razvoj kreativnih potencijala. U protivnom, negativno utičmo $i$ dovodimo do pada dječije kreativnosti. Cilj ovog rada je naglasiti vrijednost igre za djetetov rąvoj, kao i osvijestiti prostor za promišjanja o mogućnostima susreta igre i kereativnosti.

Ključne riječi: igra, kreativnost, stvaralačka igra, igra pretvaranja

\section{UVOD}

Živimo u svijetu koji se ubrzano i nepredvidivo mijenja. Zbog toga, nemoguće je precizno znati koje će vještine djeci biti potrebne u budućnosti. Prema podacima Svjetskog ekonomskog foruma 65\% predškolske djece koja danas polaze u osnovnu školu na kraju će završiti radeći poslove koji danas još i ne postoje (2016: 4). Upravo zbog navedenog, fokus treba biti na razvoju transferabilnih vještina koje će pomoći djeci da se uspješno suoče s nadolazećim izazovima, a jedna od tih je upravo kreativnost. Kao takva, potrebna je u obrazovnom 
sistemu, a jedan od mogućih modusa njenog podsticanja jeste upravo kroz igru. Dakle, imperativ je već od predškolskog perioda raditi na poticanju kreativnih potencijala, zato što zanemarivanje poticanja kreativnosti u predškolskom periodu može značajno ugroziti postojanje budućeg kreativnog uma odrasle osobe. Sve vrste igara predstavljaju plodonosno tlo za kultiviranje kreativnosti u predškolskom periodu. Naprimjer, u okviru simboličke igre djeca koriste maštu koja utiče na razvoj njihovog kreativnog potencijala. Osim toga, simbolička igra pruža djeci mogućnost izražavanja različitih procesa: kognitivnih, afektivnih i međuljudskih, a svi su oni važni za kreativnost. Tokom konstruktivnih igara, djeca sarađuju, istražuju i rješavaju probleme. Sve unaprijed navedene aktivnosti su $u$ funkciji razvoja djetetovog kreativnog potencijala. Igre uloga podupiru dječija različita razmišljanja i kognitivnu fleksibilnost što također predstavlja osnovne sastavnice kreativnost (Đuranović i sar., 2020). Iz navedenog, proizilazi da je kreativni um onaj koji je razigran $\mathrm{i}$ da različite vrste igara doprinose razvoju kreativnosti. Zbog toga je bitno omogućiti djeci dovoljno vremena za igru, da ne bismo svjedočili padu kreativnosti budućih generacija.

\section{POLAZNE OSNOVE KREATIVNOSTI I IGRE}

Potreba za stvaralaštvom postoji otkad postoji i ljudsko društvo, baš kao i potreba za igrom. Da bismo govorili o odnosu igre i kreativnosti na samom početku moramo upoznati ove fenomene.

Jedna od bitnih vještina potrebnih za snalaženje u svakodnevnom životu jeste kreativnost. Kreativnost je postala odlučujući element duha vremena 21. stoljeća. Posljednjih godina ova riječ je postala jedna od najčešće korištenih riječi našeg jezika, lišena bilo kakvog jasnog značenja ili metoda za promociju stvaralaštva u vrtićima, školama i društvu (Brierley, 2016).

Sternberg (1999) navodi da je kreativnost pitanje stava prema životu jednako kao i pitanje nečijih sposobnosti. Bilo da kreativnost posmatramo kao stav prema životu ili, pak, kao pitanje sposobnosti, ona je značajna i na individualnom i na kolektivnom planu. $\mathrm{Na}$ individualnoj razini, kreativnost ima svoju ulogu u rješavanju svakodnevnih životnih situacija, dok na društvenoj razini kreativni 
napori omogućuju spoznavanje stvarnih problema u svijetu, njihovo rješavanje, a samim tim, i aktivno oblikovanje budućnosti.

Niz istraživanja (Holmes \&Moedt,2020; Growe \&Wagner,2020; Burgess \& Limerick,2013; Fine i sar., 2021) govore o kreativnosti unutar različitih konteksta, bile to odgojno-obrazovne ustanove, radno okruženje, svakodnevne životne situacije, slobodno vrijeme. Tako Sternberg (1999) navodi kako mala djeca prirodno iskazuju kreativnost. Prostor za kreativnost dodatno opada u starijim razredima osnovnih i srednjih škola. I drugi empirijski dokazi upućuju na to da kreativnost pojedinaca opada kako se broj godina $\mathrm{u}$ formalnom obrazovanju povećava (Dacey \& Lenon, 1998; Simonton, 1983). Jedan od inhibirajućih faktora kreativnosti može biti upravo sam nastavnik, budući da nastavnikovi osobni stavovi prema fenomenu kreativnosti ili spobnostima učenika utiču na razvoj kreativnosti kod učenika. Ukoliko nastavnik ne radi na razvoju osobne kreativne kompetencije, onda je teško očekivati da može podsticati razvoj kreativnih potencijala svojih učenika. Zbog toga je bitno naglašavati značaj kreativnosti i kreativnih pristupa u nastavi već na inicijalnom stupnju obrazovanja studenata koji pretenduju da se bave nastavničkim pozivom.

Što više budemo spremni da razumijemo prirodu kreativnosti i njenu vezu s učenjem i motivacijom, to ćemo biti bolje opremljeni da razvijamo i potičemo kreativnost svojih učenika, kako ne bismo svjedočili Sternbergovim riječima koje spominje u knjizi Teaching for Creativity: The Sounds of Silence. On navodi kako postoje stotine knjiga i hiljade članaka o tome kako naučiti djecu da kreativno razmišljaju. Međutim, kada uđete u učionicu, vjerovatno nećete vidjeti puno predavanja za kreativno razmišljanje (Sternberg, 2015). Shodno navedenom, napori trebaju biti usmjereni ka stvaranju učionica $u$ kojima će kreativnost, prije svega, biti valorizirana i prepoznata. Drugim riječima, težiti da učionice uistinu postanu prostori unutar kojih djeca mogu sarađivati, uživati, i učiti. Sve navedeno moguće je ostvariti kroz igru, ukoliko je ne percipiramo kao djetinjastu, slučajnu i neučinkovitu.

\section{POTICANJE I RAZVIJANJE KREATIVNOSTI KROZ IGRU}

O igri je dosta toga rečeno i napisano. Koncept igre je teško definirati i ne postoji konsenzus o jednoj definiciji. Možemo reći da je igra 
slobodna, spontana aktivnost koja se dešava bez ikakve vanjski nametnute nužnosti. Proizilazi iz unutrašnje potrebe, ima svoju logiku koja se razlikuje od logike spoljašnje realnosti, kako je odrasli često razumiju. Djeca obično izražavaju radost tokom igre i uranjaju se $u$ aktivnost koja se obično održava neko vrijeme (Ackermann i sar.). Ako je igra slobodna aktivnost dijete joj ne pristupa s nekim konkretnim ciljem. Dijete se igra da bi se igralo. To ne čini da bi razvijalo neke sposobnosti. Ali, s druge strane ono to kroz igru upravo i čini. Niz je sposobnosti koje dijete spontano razvija kroz igru. Dok se ranije igra posmatrala kao aktivnost koja pruža zabavu, razonodu, kao mogućnost da se ispuni slobodno vrijeme, danas se na igru gleda kao na najvažniju aktivnost djeteta. Igra nesumnjivo doprinosi svestranom razvoju djeteta. U najširem smislu, razvija motoričke, socijalne, emocionalne, radne, te intelektualne sposobnosti djeteta.

Pored toga što je igra spontana, slobodna djelatnost čiji smisao se nalazi u samoj njenoj aktivnosti, postoji još niz obilježja igre. Tako Matejić (1978) kroz pristupe igri navodi i sljedeće karakteristike:

1. igra je simultano ponašanje sa sljedećim odlikama: divergentnost, nekompletnost, neadekvatnost;

2. igra je autotelična aktivnost iz koje slijedi: da posjeduje vlastite izvore motivacije, da je proces igre važniji od ishoda akcije, dominacija sredstava nad ciljevima, odsutnost neposrednih pragmatičnih učinaka;

3. igra ispunjava privatne funkcije igrača tj. oslobađa od napetosti i rješava konflikte, te reguliše fizički, spoznajni i socio-emocionalni razvoj;

4. igra se izvodi u stanju optimalnog motivacijskog tonusa iz čega slijedi zaključak da se ona javlja u odsutnosti neodložnih bioloških prisila i socijalnih prijetnji (Matejić,1978: 82).

S druge strane, Klarin (2017) navodi sljedeće karakteristike igre: aktivnost, pustolovina i rizik, uključenost, smislenost i značenje, socijabilnost i interaktivnost, simboličnost, terapeutski karakter i dobrovoljnost. Else (2014) kao temeljna obilježja igre navodi da je ona proces, rezultat samostalnog izbora, dovoljno sigurna, predstavlja cjelokupno iskustvo, oslobođena je od vremena, prevladava znatiželja, 
zadovoljstvo, različita je za svakog i sama sebi je svrha (prema Klarin, 2017).

Ovako postavljene odlike ukazuju na značaj igre i igrovnih aktivnosti. Možemo reći da su mogućnosti igre neograničene. Igra je aktivnost, ponašanje, proces, cilj i smisao. Ona je simbol svijeta i tu se ogleda njena neprocjenjiva vrijednost. Ako govorimo o dječijoj igri, onda je posmatramo kao najvažniji posao djeteta koji olakšava proces učenja. Igra može podržati učenje ako su djeca aktivno uključena, kognitivno angažirana; misle na osnovu iskustva, imaju socijalne partnere, interaktivno proširuju igru i doživljavaju radost (Zosh i sar., 2018). Ono što se, nažalost, dešava je da se igra u društvu često smatra suprotna učenju. Ta je dihotomija između igre i učenja čak predstavljena u našem govornom jeziku kada koristimo izraze kao što je "Ne igraj se olovkom", čime impliciramo da je igra nešto negativno i nepotrebno ili „Ako završite ovaj zadatak, možete ići da se igrate“, što podrazumijeva da je igra manje važna $i$ da joj se može pristupiti samo ako je važan posao završen. Ovaj fenomen Slatina (2005) definiše kao "marginalni", ukazujući na to da pedagošku težinu igre ne vide mnogi obrazovani ljudi, stoga tumače igru kao nešto što je suprotno učenju, posebno školskom. Istraživanja sugerišu da igra doprinosi razvoju akademskih sposobnosti djece, kao i bitnih vještina, uključujući saradnju, komunikaciju, samopouzdanje, kreativne inovacije i kreativno razmišljanje (Golinkoff \& Hirsh-Pasek, 2016; Zosh \& sar., 2018).

Osim gore navedenih benefita igre, treba spomenuti da igra ima ulogu u razvoju kompetencija. Kroz igru djeca mogu iskusiti i oblikovati svijet sa svojim vlastitim uvjerenjima i vrijednostima koja se razlikuju od stvarnosti. Djeca tada imaju priliku iskoristiti svoje kreativne vještine razmišljanja i podijeliti svijet koji su stvorili sa svojim vršnjacima. Djeca također mogu da vježbaju svoje pregovoračke vještine tokom aktivnosti igre, jer je međusobno djelovanje složeno. Ona mogu učiti od svojih vršnjaka koji su možda različite dobi ili imaju različita iskustva, pa će im učenje biti izazov u igri. Najbolje uče onda kada je njihova puna pažnja osvojena, što se često događa tokom igre. Dakle, igra postaje izvor učenja koji je posebno neodvojiv tokom predškolskog obrazovanja. No, želimo naglasiti da njena uloga ne treba da se završi na tom stepenu, već treba da se nastavi, čak i tokom visokog obrazovanja, pa i dalje. Igra nije svojstvena samo djeci. Postoje i igre 
namijenjene odraslima. U tom slučaju, igra je suprotstavljena ozbiljnosti života, brizi i radu - pojavljuje se kao ono što je neozbiljno, neobavezujuće, kao povremeno popuštanje životne stvarnosti, kao pauza i odmor, kao zabava za vrijeme besposlenih sati, kao zbijanje šale i nerada punog užitka (Fink, 2009). Samim tim što je igra suprotstavljena ozbiljnosti života i omogućuje odmak od svakodnevnih napetosti, ona stvara postavke za sadržajniji i ispunjeniji život. Iako se ona u odrasloj dobi javlja kao neobavezujuća aktivnost, činjenica je da igra svjesno ili nesvjesno traži kritičko i kreativno preispitivanje stvari. Kroz nekoliko eksperimentalnih studija sa studentima analizirao se uticaj različitih vrsta igara na kreativne performanse. Hutton i Sundar (2010) otkrili su da su studenti uspješniji na testu kreativnosti nakon igranja videoigara. U drugom istraživanju, studenti su povećali svoje kreativne rezultate nakon igranja maštovitih igara uloga (Karwowski \& Soszynski 2008). Studenti psihologije koji su obavljali zadatak pisanja zamišljajući sebe kao sedmogodišnjake postigli su veći rezultat na testu kreativnosti u odnosu na kontrolnu grupu. U studiji se navodi da razmišljanje o sebi kao djetetu, makar i na kratko, olakšava zaigrane i kreativne procese razmišljanja (Zabelina \& Robinson 2010). Temeljna odrednica igre postaje kreativnost iz razloga što same igrovne aktivnosti traže kreativan pristup. Igra je, pored toga, izvor informacija o unutrašnjem stanju svake osobe. Odrasli i djeca u igri konstantno preispituju svoje uloge. I ne samo to. Oni tragaju, iznalaze, operacionaliziraju, konstruišu, analiziraju, sintetiziraju i evaluiraju elemente i cjeline, koje kroz aktivnosti postaju novine. Duhovnounutrašnji svijet svake individue se razvija kroz kreativnu igru. U skladu s tim, bavljenje igrom ili sudjelovanje u njoj traži posjedovanje određenih sposobnosti poput upornosti, dosjetljivosti, originalnosti, fluentnosti, elastičnosti u mišljenju, prevladavanje neizvjesnosti, divergentno i kritičko promišljanje, ali i nudi priliku za njihovo razvijanje. Igra često pruža djeci i odraslima mogućnosti da razviju svoje kreativne vještine razmišljanja, poput omogućavanja gledanja situacija iz različitih perspektiva, razmišljanja o alternativnim strategijama za rješavanje problema i vježbanje razmišljanja na različite načine, a sve bez kaznenih posljedica (Ackermann i sar., s.a).

Kada smo iznijeli neka promišljanja, nemoguće je ne upitati se da li igra razvija kreativne crte ličnosti ili su možda kreativne crte ličnosti pretpostavka za planiranje, realiziranje, upravljanje, te vrednovanje 
igre. Unutar društvenih i humanističkih nauka fenomene je nekad nemoguće, pa i nepotrebno tumačiti u odnosima uzroka i posljedica. Umjesto ovoga bolje bi bilo govoriti o položaju kreativnosti unutar igre, odnosno igre unutar kreativnog procesa. Između igre i kreativnosti postoji tijesna veza. Za igru se ističe da je ona infantilna forma ljudske sposobnosti za prerađivanje iskustva, posebno putem eksperimentisanja i planiranja. Ona je prilika za novu upotrebu iskustva, za njegovu transformaciju u novim okolnostima. Igra ima i trajne učinke na razvoj originalnosti, što je bitno svojstvo stvaralaštva. Inventivnost, simboličnost, spontanost su odrednice igre, ali i kreativnosti (Trnavac, 1979). Igra ima ulogu u razvijanju sposobnosti koje su značajne za rješavanje problema. Kako bi ispitali ulogu igre u razvoju dječijih vještina rješavanja problema, Ramani i Brownell (2014) pregledali su članke koji su istraživali saradničko rješavanje problema predškolaca u kontekstu društvene igre. Djeca su u stanju uspostaviti zajedničke ciljeve u okvirima društvene igre koji uključuju aktivnosti u ranom djetinjstvu, poput gradnje i sociodramatične igre (Mussen, Carmichael \& Hetherington, 1983). To se događa kada djeca sudjeluju s vršnjacima u aktivnostima, pri čemu vježbaju koristeći svoje vještine razrade i fleksibilnost, a koje predstavljaju aspekte divergentnog razmišljanja. Uz to, učešće u društvenoj igri omogućuje djeci razvijanje vještine pregovaranja i rješavanja sukoba, jer moraju identificirati problem i razgovarati o njemu kako bi pronašli rješenje koje je svima prihvatljivo (Raman \& Brownell, 2014). Budući da ciljeve u igrama određuje dijete i oni se mijenjaju kroz igru, djeca kontinuirano koriste svoje vještine divergentnog mišljenja koje omogućava razvoj u ovom području.

\section{STVARALAČKA IGRA I IGRA PRETVARANJA}

Kroz rad smo nastojale prikazati da sve vrste igara imaju značajnu ulogu u razvoju djece. U narednom dijelu rada ćemo se kratko baviti stvaralačkom igrom i igrom pretvaranja kao posebnim formama igre koje mogu značajno doprinijeti razvoju kreativnih potencijala. Već smo naglasili da bi bilo ispravnije govoriti o stvaralaštvu unutar (svake) igre, ali stvaralačku igru i igru pretvaranja mnogi autori posebno ističu unutar klasifikacija, pa ćemo nastojati prikazati neka od njihovih najznačajnijih obilježja. 
Stvaralačke igre su one koje dijete samostalno osmišljava i realizira. Temeljno obilježje ove igre je maštovitost. U dječijoj igri mašta se razmahuje. Ona djetetu omogućava da ostvari ili doživi ono što u realnom svijetu, s obzirom na svoje skromne mogućnosti ili zbog svoje zavisnosti, ne može da učini. U igri dijete samo usmjerava svoju maštu, čini ono što mu je volja, te je ona vezana sa zadovoljstvom. U igri dijete postaje „gospodar situacije“ (Mitić \& Korene, 1983). Pored maštovitosti, još ranije smo pisali o obilježjima igre, kao što su aktivnost, sloboda, spontanost, divergentnost u mišljenju, preuzimanje rizika, maksimalna uključenost, smislenost i značenje, socijabilnost i interaktivnost, zadovoljstvo, simboličnost. U kontekstu kreativnosti postoji mnoštvo teorija. Jedna od njih je Investicijska teorija koju su razradili Sternberg i Lubart. Prema ovoj teoriji, postoji šest resursa kreativnosti koji se uvijek nalaze u konfluentnom odnosu. Bitan resurs kreativnosti se odnosi na ličnost. Veliki broj istraživanja govori o povezanosti između osobina ličnosti i kreativnosti (Sternberg, 2006a, Sternberg, 2006b). Ovdje se naročito naglašavaju sljedeće osobine ličnosti: sklonost ka savladavanju poteškoća, sklonost ka preuzimanju razumnog rizika, sklonost ka toleranciji dvosmislenosti, samoefikasnost, odupiranje uobičajenim konvencijama. Slične osobine ličnosti navodi i Kvaščev (1981) nalazeći da su emocionalna stabilnost, sklonost riziku, društvena hrabrost, neinhibiranost, spontanost, maštovitost, istraživački duh, nezavisnost, pronicljivost i odsustvo frustriranosti značajni prediktori kreativnih dostignuća u kasnijem uzrastu (prema Pušina, 2020). Uporedimo li osobine ličnosti koje dolaze do izražaja u igri i koje se razvijaju tokom igre, i osobine ličnosti koje odlikuju kreativne osobe, vidjet ćemo da postoji visok nivo saglasnosti između ovih osobina. To nas dalje upućuje na zaključak da kroz igru dijete može razvijati svoju kreativnost. Ali, to i dalje ne znači da će ono razviti te sposobnosti. Zašto? Osobine ličnosti su samo jedan od resursa kreativnosti. Pored toga, postoji još pet resursa: intelektualne sposobnosti, intelektualni stilovi, znanje, motivacija i okruženje. Naveli smo da se svi resursi kreativnosti nalaze u sadejstvujućem odnosu. Intelektualne sposobnosti kao jedan od resursa omogućuju povezivanje analitičke i praktične inteligencije. Igra je učenje koje traži prikupljanje i sistematiziranje saznanja. Djeca kroz igru imaju priliku da konstruišu stvarnost u onom obliku koji im omogućava njihovo iskustvo. Ideacija (stvaranje ideja), traganje za idejama, procjena ideja i uvjeravanje 
drugih u vrijednost ideja su obilježja igre, ali i kreativnog procesa. Uzmimo za primjer još i okruženje. Okruženje je jako bitan faktor za razvoj kreativnosti. Kada govorimo o okruženju, onda mislimo na okruženje u najširem smislu, uključujući kulturu, društvo, ekonomsku razvijenost, politički sistem i dr. Takvo okruženje uključuje i bitne sastavnice koje su na nižem nivou, mikronivou poput igračaka, dostupnosti materijala, boja, fizičkog okruženja, kanala komunikacije. Ponekad čak i trivijalni detalji - poput rasporeda namještaja, dostupnih materijala i tehnologije igraju ključnu ulogu u postizanje pozitivnih iskustava učenja koja mogu odrediti ishode učenja kod učenika. Samo s kreativnim okruženjem, kreativnim obrazovnim programima i kreativnim načinima poučavanja, moći ćemo poticati kreativno razmišljanje. Okruženje je još jedan faktor koji lako može pospješiti ili inhibirati razvoj kreativnosti kod djece. Da bi poticalo razvoj stvaralačkih sposobnosti, ono treba biti manje restriktivne prirode, kreirano tako da podržava istraživanje, kooperativnu igru i omogućuje djeci da spontano stvaraju. Odgovornost za kreiranje poticajnog okruženja u prvom dijelu života djeteta pripada roditeljima. Roditelj, odnosno odgajatelj je prva osoba koja je nositelj odgoja, između ostalog i kreativnog odgoja. Svojim pristupom, ponašanjem i osobinama ličnosti on može da potiče razvoj kreativnosti kod djeteta uključivanjem u igru i pružanjem odgovarajuće okoline u kojem kreativno razmišljanje može procvjetati. Značajne se osobine odgajatelja poput dosljednosti, mudrosti, ljubavi prema djeci, objektivnosti, prilagodljivosti, ali i kreativnosti. Razvijanje i podsticanje kreativnog ponašanja se može vršiti na različite načine. S obzirom na složenost samog koncepta kreativnosti, ti načini zahtijevaju sistemski i sistematski pristup. Neizvjesnost promjena kojima smo izloženi dodatno opravdava potrebu za jednim takvim pristupom. Kreativnost se najbolje uči kreativnošću. Stoga, takav pristup treba biti kreativan.

Igra pretvaranja je kreativno djelo (radnja). Nekoliko detaljno urađenih studija pružaju dokaze da igra pretvaranja olakšava divergentno mišljenje kod djece predškolske dobi (Dansky 1980; Dansky \& Silverman 1973). U igri pretvaranja možemo posmatrati kreativnost onako kako se pojavljuje, iz minute u minutu. Teoretičari i istraživači u oblastima dječijeg razvoja, dječije psihoterapije, kreativnosti, osobnosti i evolucije došli su do zaključka da su igra pretvaranja i kreativnost povezani. Vjerujemo da ovi istraživački nalazi potvrđuju povezanost jer 
igra pretvaranja pruža djeci mogućnosti da izraze mnoge različite procese - kognitivne, afektivne i međuljudske - važne za kreativnost. Igra pretvaranja predstavlja otvoren događaj i služi kao sredstvo/alat koje dijete koristi u različite kreativne svrhe.

Istraživači kreativnosti, počevši od Guilforda, još od 1950. godine prepoznali su kognitivne sposobnosti posebno važne za kreativnost, a mnoge od njih također karakteriše igra pretvaranja, kao divergentno razmišljanje, široke asocijativne vještine, uvid, kognitivna fleksibilnost i perspektiva (Russ, 2014). Divergentno razmišljanje kao važan faktor kreativne proizvodnje, uključuje sposobnost generiranja različitih ideja (Runco, 1991). Sposobnost stvaranja mnogih ideja, širokog pretraživanja i fleksibilnog razmišljanja povećava izglede da će osoba kreativno riješiti problem ili proizvesti umjetničko djelo. Te se kognitivne sposobnosti javljaju u igri i one se, kao što su sugerisale Singer i Singer (1990), vježbaju u sigurnoj areni igre pretvaranja. U novije vrijeme, istraživanja su ispitivala afektivne procese u kreativnoj produkciji. Važni afektivni procesi koji se dešavaju i u igri pretvaranja i u kreativnosti uključuju izradu afektivnih tema u mašti i pamćenju, doživljavanje emocija (naročito pozitivnih emocija), kognitivne integracije afekta i doživljavanje radosti u kreativnom izražavanju. Igra pretvaranja omogućava izražavanje mnogih kognitivnih sposobnosti i afektivnih procesa važnih za kreativnost.

Fein igru također smatra prirodnim oblikom kreativnosti. Njen pogled slaže se s konceptom koji je Richard (1990) iznio o svakodnevnoj kreativnosti (1990). Za djecu je kreativnost u svakodnevnom životu često u obliku igre pretvaranja. Igra pretvaranja postaje tada dječiji kreativni proizvod. Do sličnih nalaza je došao i Russ (2016). Primijetio je da su kognitivni i emocionalni procesi uključeni u igru pretvaranja i kreativnost slični. Sociodramatična igra pruža priliku djeci da razviju svoje kreativne vještine razmišljanja, jer mogu koristiti predmete za simbolizaciju drugih predmeta (štap mogu pretvoriti u štapić), izmišljati priče, koristiti se igranjem uloga za nametanje različitih tema kao što su jelo, čudovišta i igre s vršnjacima. Budući da se uvjeti igranja za svijet djece obično mijenjaju, djeca moraju neprestano revidirati pravila aktivnosti, što omogućava razvijanje njihovih kreativnih sposobnosti (Pramling Samuelsson \& Johansson, 2006). 
Russ (2014) zaključuje da postoji pet načina na koji igra pretvaranja pomaže djetetu da postane kreativniji: (1) igra uključuje vježbanje stvaranja asocijacija što je važan dio divergentnog razmišljanja; (2) igra pretvaranja vodi upotrebi simbola, rekombinaciji ideja i manipuliranju prikaza objekata, koji su dio transformacijske sposobnosti i sposobnosti uvida; (3) igra omogućuje izražavanje i doživljavanje pozitivnog uticaja, što je značajno za kreativnost; (4) igra pretvaranja se omogućava igračima da izražavaju i razmišljaju o pozitivnim i negativnim uticajima na teme koje tokom vremena vode dijete da razvija sposobnost pristupa sjećanjima i asocijacijama koje pomažu $u$ kreativnom rešavanju problema; (5) igra pomaže djetetu da razvije kognitivnu strukturu (Russ, 2014:50).

Igra pretvaranja i kreativnost su prirodno povezani kako dijete koristi fantaziju, simbolizam i divergentno razmišljanje za tkanje konteksta, priča i likova. Djeca i odrasli u igri i stvaralaštvu stvaraju različite prostore, polja ili kontekste. Edmiston (2008) navodi da djeca i odrasli u igri i stvaralaštvu dijele realni, svakodnevni društveni prostor, grade zamišljen prostor kao mogući prostor i koautorski prostor koji nastaje preklapanjem prethodna dva i oblikuje njihova značenja. U koautorski prostor oni unose dijelove svog zamišljenog i realnog prostora $\mathrm{i}$ koristeći ih kao osnovu zajedno izgrađuju nove forme odnosa (Krnjaja, 2010). Dakle, tu govorimo o pojedinim elementima kreativnosti, dotičući se pri tome i interaktivnog odnosa između realnog i imaginativnog prostora. Interakcija između ova dva svijeta otvora široke mogućnosti za kreativno djelovanje. Kreativnost u službi čovjeka znači biti sposoban rješavati probleme u okruženjima koja su sve kompleksnija. Igru treba prepoznati kao osnovni posao djeteta. Igra podučava djecu kako da kreativno uče, kritički promišljaju i postanu kreatori svog života i svoje budućnosti. U svakodnevnici dječijeg života treba prepoznati mogućnosti susreta igre i stvaralaštva, te ih podržavati svim raspoloživim resursima.

\section{ZAKLJUČAK}

Kroz rad su prikazane neke od naznaka kreativnosti, igre, kreativne igre. Kreativnost je danas prepoznata kao jedna od ključnih kompetencija za život u 21. stoljeću. Razvijanje i podsticanje kreativnog ponašanja kod djece zahtijeva sistemski i sistematski 
pristup. To je, prije svega, proces kojeg ne smijemo posmatrati kao nešto usputno. Umijeće odgoja i obrazovanja se ne ogleda u nametanju ideja, stavova, vrijednosti, već je u svemu tome potrebno pobuditi duh, razmišljanje i kreativnost. Jedno je sigurno, moramo izvršiti drastične promjene i nastaviti zagovaranje kreativnosti na svim stupnjevima, tako da naši školski sistemi i nastavnici budu sigurni da ih istražuju.

Između igre i kreativnosti postoji uska povezanost. Kreativnost je polazište, ali i ishodište promišljanja o novim mogućnostima. Kroz igru do izražaja dolaze emocionalna stabilnost, upornost, inicijativa, sloboda, maštovitost, samostalnost, spontanost, istraživački duh. Sve ove komponente su značajni prediktori kreativnih postignuća tokom osnovnoškolskog, srednjoškolskog, visokoškolskog obrazovanja kao i profesionalnog razvoja.

Svaka igra može biti kreativna, stoga ju je potrebno poticati. Na kraju, kreativnost je bogata i lijepa individualna ljudska osobina koju imaju svi pojedinci i trebamo je njegovati.

\section{LITERATURA:}

Ackermann, E., Gauntlett, D., Whitebread, D., Wolbers, T., \& Weckström, C. (s.a.). The future of play. Defining the role and value of play in the 21st century. LEGO Learning Institute. Dostupno na: https://www.realplaycoalition.com/wp-content/uploads/2018/11/TheReal-Play-Coalition_Value-of-Play- Report.pdf, datum posjete: 6 . august 2020. god.

Brierley, D. L. (2016) Stotinu miliona sadašnjih sudbina: Voditi učenike u njihovim aspiracijama kroz labirinte našeg vremena. Zagreb: IWP.

Burgess,R. \&Lukersmith, S (2013) The perceived importance and the presence of creative potential in the health professional's work environment. Ergonomics. 56 (6), 922-934, Doi: 10.1080/00140139. 2013. 779033.

Dacey, J. S., \& Lennon, K. H. (1998) Understanding creativity: The interplay of biological, psychological, and social factors. San Francisco, CA: Jossey-Bass.

Dansky, J. L. (1980) Make-Believe: A Mediator of the Relationship between Play and Associative Fluency. Child Development.51, 576-579. 
Dansky, J. L., \&Silverman,I.W. (1973) Effects of Play on Associative Fluency in Preschool-Aged Children. Developmental Psychology. 9, 38-43

Đuranović, M., Klasnić, I. \& Matešić, I. (2020) Poticanje dječije kreativnosti u predškolskim ustanovama. Školski vjesnik. 69 (1), 89-110.

Edmiston, B. (2008) Forming Ethical Identitie in Early Childhood Play. New York: Routledge.

Else, P. (2014) Making Sense of Play. New York: McGraw-Hill.

Fine, P.A., Friedlander, K.J. \& Morse, K.F. (2021) Creativity and Leisure During COVID-19: Examining the Relationship Between Leisure Activities, Motivations, and Psychological Well-Being. Frontiers in Psychology.12: 609967. doi: 10.3389/fpsyg. 2021. 609967

Fink, E. (2000) Igra kao simbol svijeta. Zagreb: Demestra, Filozofska biblioteka Dimitrija Savića.

Golinkoff, R. M., Hirsh-Pasek, K. (2016) Becoming Brilliant: What Science Tells Us About Raising Successful Children, 3. Washington, D.C.: American Psychological Association.

Growe, A. \& Wagner, M. (2020) Creativity-enhancing work environments: Eventisation through an inspiring work atmosphere in temporary proximity. Raumforschung und Raumordnung / Spatial Research and Planning. 78 (1), 53-70. https://doi.org/10.2478/rara-2019-0039

Hirsh-Pasek, K., Golinkoff, R. M., Berk, L. E., Singer, D. G. (2009) A Mandate for Playful Learning in Preschool. New York: Oxford University Press.

Holmes, R.K. \& Moeedt, K. (2018) The effects of purposeful play after shared storybook readings on kindergarten children's reading comprehension, creativity, and language skills and abilities, Early Child Development and Care, 1-16.Doi: 10.1080/03004430. 2018. 1496914.

Hutton, E. \& Sundar, S. (2010) Can Video Games Enhance Creativity? Effects of Emotion Generated by Dance Dance Revolution." Creativity Research Journal 22 (3) 294-303.

Karwowski, M. \& Soszynski, S. ( 2008) How to Develop Creative Imagination? Assumptions, Aims and Effectiveness of Role Play Training in Creativity (RPTC) Thinking Skills and Creativity 3: 163-71.

Klarin, M. (2017) Psihologija dječje igre. Zadar: Sveučilište u Zadru.

Krnjaja, Ž. (2010) Igra, stvaralaštvo, otvoreni vaspitni system - šta ih povezuje?. Nastava i vaspitanje, 59 (2), 264-277 
Kvaščev, R. (1981) Psihologija stvaralaštva. Beograd: Zavod za udžbenike i nastavna sredstva.

Matejić, Z. (1978) Simbolička igra kod dece predškolskog uzrasta (magistarski rad). Beograd: Filozofski fakultet.

Mitić, V., Korene, Z. (1983) Igra i igračke. Beograd Sarajevo: Zavod za udžbenike i nastavna sredstva i Svjetlost.

Mussen, P. H., Carmichael, L., Hetherington, E. M. (1983) Handbook of child psychology (4th ed.). New York: Wiley.

Pramling Samuelsson, I., Johansson, E. (2006) Play and learning - inseparable dimensions in preschool practice. Early Child Development and Care, 176 (1), 47-65. Dostupno na:

https://doi.org/10.1080/0300443042000302654, datum posjete: 6 . august 2020. god.

Pušina, A. (2020) Ljudska kreativnosti: Psihologijski modeli. Sarajevo: Filozofski fakultet Univerziteta u Sarajevu.

Ramani, G. B., \& Brownell, C. A. (2014) Preschoolers' cooperative problem solving: Integrating play and problem solving. Journal of Early Childhood Research, 12 (1), 92-108. Dostupno na: https://www.researchgate.net/publication/263502490

Preschoolers'_cooperative_problem_solving_Integrating_play_and_ problem_solv_ ing, datum posjete: $\overline{6}$. august 2020 . god.

Richards, R. (1990) Everyday Creativity, Eminent Creativity, and Health: Afterview for CRT Issues on Creativity and Health. Creativity Research Journal, 3 (4), 300-326.

Runco, M. (1991) Divergent Thinking. Ablex Publishing Corporation.

Russ, S. W.(2014) Pretend Play in Childhood: Foundation of Adult Creativity. American Psychological Association.

Russ, S.W. (2016) Play in Child Development and Psychoterapy: Toward Emirically Supported Practice. Routledge.

Simonton, D.K. (1983) Formal education, eminence and dogmatism: The curvilinear relationship. Journal of Creative Behavior, 17 (3), 149162.

Singer,D. G. \& Singer, J. L. (1990) The House of Make Believe: Children Play and the developing instruction. Harward University Press.

Slatina, M. (2005) Od individue do ličnosti: uvođenje u teoriju konfluentnog obrazovanja. Zenica: Dom štampe. 
Sternberg, R. J. (1999) Uspješna inteligencija: kako praktična i kreativna inteligencija određuju uspjeh u životu. Zagreb: Barka.

Sternberg, R. J. (2006a) The Nature of Creativity. Creativity research journal, 18 (1), 87-98

Sternberg, R. J. (2006b) Creating a Vision of Creativity: The First 25 Years. Psychology of Aesthetics, Creativity and the Arts, 8 (1), 212.

Sternberg, R. J. (2015) Teaching for Creativity: The Sounds of Silence. Psychology of Aesthetics, Creativity, and the Arts, 9 (2), 115-117

Trnavac, N. (1979) Dečja igra: Opšta pedagoška pitanja. Gornji Milanovac: Dečje novine.

Turner, V. (1982) From ritual to theatre: The human seriousness of play. New York: PAJ.

World Economic Forum. (2016) The future of jobs: Employment, skills and workforce strategy for the fourth Industrial Revolution. Dostupno na: http://www3.weforum. org/docs/WEF_Future_of_Jobs.pd.datum posjete: Septembar 6. 2019.

Zabelina, D. \& Robinson, D. (2010) Child's Play: Facilitating the Originality of Creative Output by a Priming Manipulation. Psychology of Aesthetics, Creativity, and the Arts 4,57-65.

Zosh, J. M., HirshPasek, K., Hopkins, E. J., Jensen, H., Liu, C., Neale, D., Whitebread, D. (2018) Accessing the Inaccessible: Redefining Play as a Spectrum.Frontiers in Psychology, 9, 1124. Dostupno na: https://www.ncbi.nlm.nih.gov/pmc/articles/ PMC6084083/, datum posjete: 6 . august 2020 . god. 
Amina Đipa, MA

University of Sarajevo

Faculty of Education

E-mail:amina.dipa1@gmail.com

\title{
RELATIONSHIP BETWEEN PLAY AND CREATIVITY: ENCOURAGING CREATIVITY THROUGH THE PLAY
}

\begin{abstract}
Countries around the world are continuously considering how to prepare children to become productive adults, while retbinking the skills and abilities needed in the workplace. One of the key skills that stands out in particular is creativity. Early childhood is a golden period in which it is extremely important to encourage creativity, and one of the ways is through play. It is known that play is the most important form of a child's learning in the preschool period, so it should be used to create creative processes that are most visible during different types of play. In times of rapid and significant change, it is important to leave space for children to play, because it has a positive effect not only on the physical, intellectual, emotional and social development of children, but also on the development of creative potential. Otherwise, we negatively affect and lead to a decline in children's creativity. The aim of this paper is to emphasize the value of play for a child's development, as well as to raise awareness of the space for reflection on the possibilities of meeting play and creativity.
\end{abstract}

Keywords: play, creativity, creative play, pretend play 
السيدة الماجستير أمينة جيبا

$$
\text { كلية التربية }
$$

amina.dipa1@gmail.com

\section{العلاقة بين اللعب والإبداع: التشجيع على الإبداع من خلال اللعب}

\section{الخلاصة}

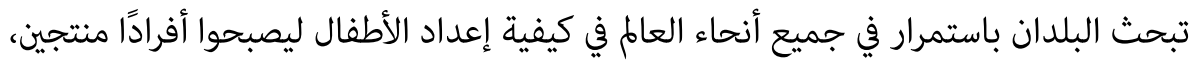

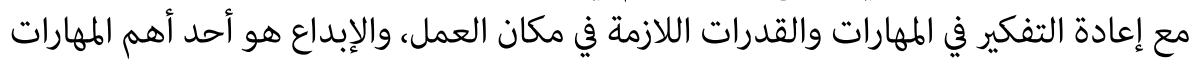

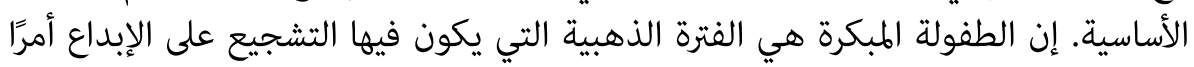

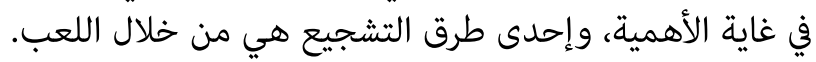

من المعروف أن اللعب هو من أهم أشكال التعلم لدى الطفل في فترة ما قبل المدرسة، ولهذا

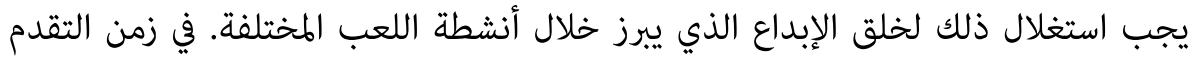

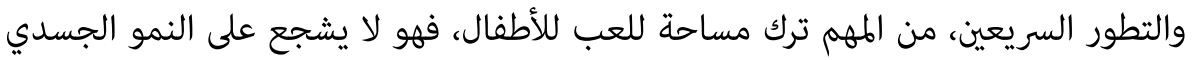

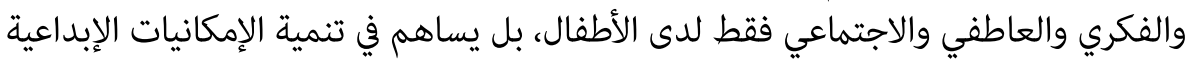
أيضًا، وإلا فإننا سنؤثر سلبًا على الأطفال وسيؤدي ذلك إعلى إلى انخفاض مستوى الإبداع لديهم. إن الهدف من هذا البحث هو التأكيد على أهمية اللعب في فو الطفل، ورفع مستوى الوعي فيما يخص فكرة الجمع بين اللعب والإبداع. الكلمات المفتاحية: اللعب، الإبداع، اللعب الإبداعي، لعبة التظاهر. 